\title{
The Inscription of Chinese Women in Citizen Textbooks of the 20th century
}

\author{
Ziyan Xin
}

\author{
Attached Middle School-Jiangxi Normal University \\ Nanchang, China \\ sdfzgjb@126.com
}

\begin{abstract}
This paper examines from textbooks whether the status of women has changed from the early to the end of the 20th century, and explores the possible underlying reasons for the changes in the status of women. It shows that the status of women has not been greatly changed during this period, and women are still bound by family and public concepts.
\end{abstract}

Keywords: Chinese Women, Citizen Textbooks, Status of women

\section{INTRODUCTION}

Under the influence of feudal ethics, Chinese women were the target of persecution and discrimination, and the status of woman has historically been lower than that of men. From the founding of the Republic of China, women have been gradually liberated. Mao Zedong, the first-generation chairman of China, took the lead in saying that men and women are equal. He claimed that "Women can hold up half of the sky." (Mao, 1893-1976) This propaganda changed the economic status and social role of Chinese women, but invented new social responsibilities of Chinese women. In a time when China assumed its entering of modern aera, the status of women is still restricted by given inscriptions.

Although the women liberty movement in $20^{\text {th }}$ century and feminist movement in the 21 th century have greatly changed ideal image of women, the inscription of women in China is still biased and misleading. 1990s, is an important transition period in China history, when western thoughts, like gender equity and women liberty awareness travelled to China. Its introduction to China in some extent contradicts with the conventions of feudal ethics and leads to the changes of women image. To study the portrayal of women in the turning of $20^{\text {th }}$ century, this research examines how women is represented in Chinese textbooks during early 1900s. Drawing on the citizen textbook in 1906, this study focuses on the representation of Chinese women in relation to social class, time, space, and role. The primary questions guiding this study are: What are ideal role models of Chinese women? What responsibility are they supposed to take? To answer this question, this study specifically examines how Chinese women are documented in given space including but not limited to home, and public space.

\section{LITERATURE REVIEW}

\subsection{The changing status of Chinese women in 20th century}

The changing status of Chinese women provides background of changing inscription of women in textbook. Many scholars study the phenomenon related to the social status of Chinese women and its reasons for the changes. Liu (2004) focuses on the change of Chinese women's status since 20th century and divides the history of the status of Chinese women into three stages. In Liu's opinion ${ }^{1}$, at the first stage (1911-1949), the Chinese Revolution overthrew the feudal monarchy that had ruled China for more than 2,000 years. Many schools for women have been established in China. At the second stage (1949-1990), New China established the socialist system. Women are involved in the construction of socialism at this time. At the third stage (1990-Present), with the popularization of the college entrance examination, women have received higher education and have been greatly improved in ideology and politics. Zhou (2014) further illustrates the reasons for the changes ${ }^{2}$. The status of Chinese women in the 20th century changed for three main reasons. First, the overthrow of the feudal dynasty led to the implementation of new policies of the new government. Second, the collision and exchange between foreign 
cultures and local Chinese traditional cultures. Third, the establishment and implementation of China's socialist system. When China entered the 20th century, the influence of the feudal political system on women has gradually diminished. The women's liberation movement has begun to deepen and the status of women in Chinese literature has changed greatly. Literary scholars created titles for women exclusively to them, allowing women to find their place in literature.

\subsection{The Politicization of Chinese Female Images in Public}

Scholars in politics study found the politicization of Chinese female images in public media. Huang (2012) conducted a study on image of Chinese women during the Cultural Revolution period (1966-1976) and found that the image of Chinese women underwent a political transformation. Huang articulates the reason of the politicalized women image in three aspects: the enforced awareness of class struggle, the idea of politics above everything, and the national-wide slogan of "times are different, men and women are the same". It concludes that the image of Chinese women in the Culture Revolution period features in temporality and normality. Quan (2019) examines the images of Chinese women in China's political propaganda paintings from 1911 Revolution to the May Fourth Movement. When the Chinese revolution overthrew the feudal ethics and ethics system, the 20th century political propaganda paintings can be used as a mirror to observe the social relations of a particular era and a space for power. Among them, the thought and practice of women's liberation and empowerment of women provide a critical contemporary perspective. Research results suggest that women only serve as a sign, a medium and an agency through which Chinese as a nation state functions and operates on. It further problematizes the de-sexualized and materialized Chinese women image.

\subsection{The "New" Chinese Women Images in Literature}

Scholars in field of literature study, especially comparative literacy examines how western idea of women travelled to China and influenced Chinese women image through literature. These studies inspire my research to examine if and how Chinese women are depicted as a self-dependent individual. Gao (2012) analyzes widely circulated books composed by female writers in early $20^{\text {th }}$ century and found that the idea of women independence was emphasized in those works. With scientific progress and western concepts of women liberation travelling to China, women were empowered in public discourse and the status of women has been improved. The reasons of the change of women image, Gao argues, is that many women moved to production positions, got rid of their long-term dependence on men in their lives, and began to share their economic status with men. These changes are reflected in the gradual emergence of some outstanding female writers and their writing on new women images. Wei (2003) analyzes the influence and significance of western female literary criticism on Chinese contemporary female writing and concluded that at the beginning, Chinese women were given equal rights by male leaders. It was not like Western revolutions, ignoring of women led to the feminist movement itself. Therefore, the spirit of Chinese feminist writing seems to come mostly from domestic practice, and less directly from the West.

\subsection{The representation of women in textbook}

Textbook studies have been an important field of study on gender representation. Some scholars critique and challenge stereotypical assumptions of women in textbooks. For instance, Olivo ${ }^{5}(2012)$ conducted a study on representation of women in American political textbook. She found that the images of women in textbook is dominantly represented by White women. Also, she found that women are left out of the main narratives and when they do appear, they appear as white, middle class women. According to Olivo's finding on the bias of women, Mutekwe and Modiba's (2012) further study how a class-based and male-centered women image in textbook influences school girl's self-image in Zimbabwe. They argued that such patriarchal approaches have a negative effect on female students' self-concepts and self-confidence.

Overall, previous studies explore the character of women image in propaganda, literature and textbooks in certain period from perspective of politics, social class and travelling ideas. Those researches inspire my study to examine women images in textbooks in its relation to social and political role ${ }^{6}$. Although researchers have also conducted various studies on Chinese woman images, not many studies examine the very construction of women image through citizen textbook in early $20^{\text {th }}$ century of China, when the long-standing feudal ethics and western idea of women independence clashed.

\section{METHOD}

This study uses a combination of content analysis and critical discourse analysis to examine textbooks for ethnic subject taught in elementary schools in China of early $20^{\text {th }}$ century ${ }^{8,9}$. The subjects are chosen because they carry the major roles of cultivating female elementary students an identification with "new" Republic of China (1912-1949) under the leadership of the Kuo-Min-tang. The version of citizen textbooks selected is The textbook for elementary women's self-cultivation (chudeng nvzi xiushen jiaokeshu) publish by Huiwen Press. 
The Compilation and Translation Service Press is first-tier textbook publisher and is the leading education press in the Republic of China. The textbook were read page by page by the author and pages that contained the texts or images of Chinese women were photocopied for analysis

\section{FINDINGS}

\subsection{Overview}

Together, nineteen images and texts of Chinese women were found in the citizen textbook. Among the nineteen Chinese woman images, thirteen Chinese woman images are related to the family and clan responsibility, four related to the social responsibility as citizen, and zero involves personal interest and hobby as independent woman. Therefore, Chinese female image is related to family and clan responsibility much more times than Chinese female image as citizen's social responsibility. Respectively, women as family/clan member, women as national citizen and women as independent individual occupy $68.42 \%, 21.05 \%$, and $0 \%$ of Chinese woman images in citizen textbook. (Some female images cannot be defined, so they are not recorded.) The detailed inscription of each image is illustrated in table I.

Table I. Inscriptions of Women in Textbook

\begin{tabular}{|c|c|c|c|}
\hline & Lesson & Total & Percentage \\
\hline $\begin{array}{l}\text { Women as } \\
\text { family/clan } \\
\text { member }\end{array}$ & 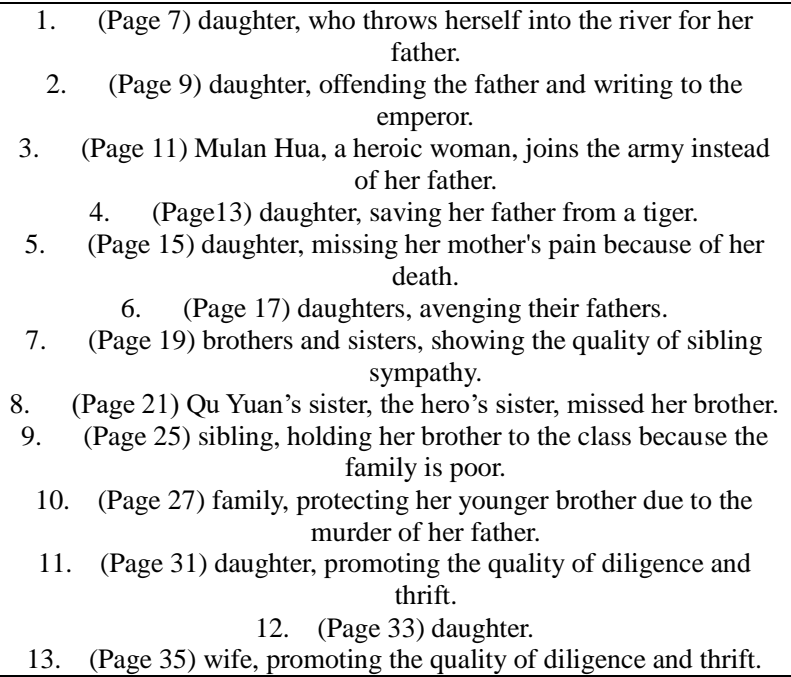 & 13 & $68 \%$ \\
\hline $\begin{array}{c}\text { women as } \\
\text { national citizen }\end{array}$ & $\begin{array}{l}\text { 1. (Page 29) the purpose of women's emergence is to promote } \\
\text { women's virtues, they should be diligent and thrifty, and they } \\
\text { should not be too luxurious. } \\
\text { 2. (Page 37) the purpose of women appearing is to promote } \\
\text { character to the public, and they should love cleanliness. } \\
\text { 3. (Page 39) the famous character Shi Xi is taken as an example to } \\
\text { promote to the public that women should be clean. } \\
\text { 4. (Page 41) take the comparison of Dongling women and Xiling } \\
\text { women as an example to promote to the public that women } \\
\text { should love to do cleaning. }\end{array}$ & 4 & $21 \%$ \\
\hline $\begin{array}{c}\text { women as } \\
\text { independent } \\
\text { individual }\end{array}$ & 0 & 0 & $0 \%$ \\
\hline $\begin{array}{l}\text { Unrecognized } \\
\text { female image }\end{array}$ & $\begin{array}{ll}\text { 1. } & \text { On the page } 23 \\
\text { 2. } & \text { On the page } 43\end{array}$ & 2 & $11 \%$ \\
\hline Total & Female appears on 43 pages & 19 & $100 \%$ \\
\hline
\end{tabular}

\subsection{Chinese Women In Between Family and Nation}

(1) Woman in Family: Daughter, wife and Sister

Chinese women are mainly sacrificing themselves to contribute to the family, and to show filial piety. For example, Hua Mulan took the place of her father in the army, and her daughter saved her father. In textbooks, Chinese women show sadness, pain, brotherhood and other qualities. The image of daughters accounted for $68 \%$ of the textbooks, a very large part of it, indicating that the textbooks want women to contribute to the family.
(2) Women in Nation-state: Sacrifice and Clean Body

In the textbooks, four women images appeared as public images, indicating that women's moral character should be hardworking and thrifty, not like luxury, and love cleanliness. In textbooks, out of 19 female images, only four female images represent the public. It shows that during this period, the image of women was still confined to the family level, but because of the progress of thought, it gradually moved from family to country. 


\section{CONCLUSION}

Chinese women were not present as independent figure who acts on her own will. In textbooks, most of the images of women come from the family and the public. Women's status is still restricted by the concept of family and public, and has not been greatly changed.

\section{REFERENCES}

[1] Gao, L. (2012). [The evolution and influence of female images in literary works]. Industrial and Science Tribune. Retrieved from https://www.cnki.net/

[2] Huang, W. (2012). [The Politicization Of Female Images During The Cultural Revolution]. Doctoral dissertation, Capital Normal University. Retrieved from https://www.cnki.net/

[3] Liu, F. (2004). [On the Change of Chinese Women's Status since 20th Century]. Social Sciences Journal of Colleges Of Shanxi. Retrieved from https://www.cnki.net/

[4] Mutekwe, E., \& Modiba, M. (2012). An Evaluation of the Gender Sensitive Nature 5.of Selected Textbooks in the Zimbabwean Secondary School Curriculum. Anthropologist, 14(4), 365-373.

[5] Olivo, C. (2012). Bringing Women In: Gender and American Government and Politics Textbooks. Journal of Political Science Education, 8(2), 131-146.

[6] Quan, H. (2019). [The construction and representation of women in the state discourse: A Critical analysis based on the Chinese political propaganda posters]. East China Normal University, Doctoral Dissertation. Retrieved from https://www.cnki.net/

[7] Wei, Z. (2003).[The Influence and Significance of Western Female Literary Criticism On Chinese Contemporary Female Writing] Master thesis, Xiangtan University. Retrieved from https://www.cnki.net/

[8] Zhou, K. (2014). [Chinese women's book]. New Weekly. Retrieved from https://max.book118.com/ 